\title{
WelFur: Sinikettujen ja hopeakettujen stereotyyppinen käyttäytyminen lisääntymiskaudella Suomessa ja Norjassa
}

\author{
Hanna Huuki ${ }^{1)}$, Anne Lene Hovland ${ }^{2}$, Tarja Koistinen ${ }^{1)}$, Jakkko Mononen ${ }^{1), 3)}$ ja Leena Ahola ${ }^{1)}$ \\ ${ }^{1)}$ Itä-Suomen yliopisto, Biotieteiden laitos, Kuopion kampus, PL 1627, 70211 Kuopio, han- \\ na.huuki@uef.fi \\ 2) Universitetet for miljø og biovitenskap, Institutt for husdyr-og akvakultuvitenskap, Postboks 5003, \\ $1432 \AA$ As, Norge \\ ${ }^{3)}$ Maa- ja elintarviketalouden tutkimuskeskus, Kotieläintuotannon tutkimus, Halolantie 31A, 71750 \\ Maaninka
}

WelFur-hankkeen tarkoituksena on kehittää arviointimenetelmä turkiseläinten hyvinvoinnin mittaamiseen tilatasolla. Tämän työn tavoitteena oli selvittää WelFur-mittaristoon kehitetyn, stereotyyppistä käyttäytymistä mittaavan mittarin käyttökelpoisuutta ja soveltuvuutta erilaisiin olosuhteisiin turkistiloilla. Lisäksi tavoitteena oli tutkia stereotyyppisen käyttäytymisen yleisyyttä eri kettulajeilla (sinikettu ja hopeakettu) ja eläintyypeillä (urokset, pennuttomat naaraat, pentuja hoitavat naaraat) lisääntymiskauden aikana.Mittaria testattiin turkistiloilla Norjassa $(\mathrm{N}=6)$ ja Suomessa $(\mathrm{N}=4)$ kesä-heinäkuussa 2011. Arvioijat tarkkailivat Norjassa yhteensä 862 kettua (5\% sinikettuja, $95 \%$ hopeakettuja) ja Suomessa 831 kettua (77\% sinikettuja, $23 \%$ hopeakettuja). Stereotyyppisen käyttäytymisen esiintyvyyttä mitattiin tarkkailemalla 8-12 ketun ryhmiä eri puolilla tilaa. Ennen tarkkailua kettujen annettiin tottua ihmisen läsnäoloon kolmen minuutin ajan, jonka jälkeen valittujen yksilöiden käyttäytymistä tarkkailtiin minuutin ajan. Tarkkailussa kirjattiin yksilöiden aktiivisuus (aktiivinen tai lepää) ja stereotyyppinen käyttäytyminen. Stereotyyppisen käyttäytymisen esiintyminen suhteutettiin aktiivisten yksilöiden määrään.Yhdellä tilalla Suomessa ja kahdella tilalla Norjassa ei havaittu stereotyyppistä käyttäytymistä. Kaikista hopeaketuista $73 \%$ ja siniketuista $57 \%$ oli aktiivisia tarkkailun aikana. Stereo-

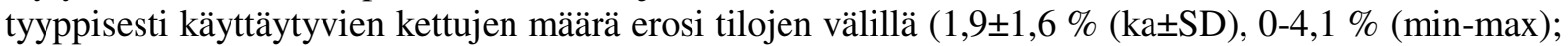
$\left.\chi^{2}: \mathrm{p}<0,05\right)$, mutta aktiivisuuteen suhteutetun stereotyyppisen käyttäytymisen määrässä ei tilojen välillä ollut eroja $(2,8 \pm 2,2 \%, 0-4,9 \%$; Kruskal-Wallis: $p>0,05)$. Stereotyyppisesti käyttäytyvien eläinten osuus kaikista tarkkailluista eläimistä (Norja: 2,1\%, Suomi: 1,8 \%) tai stereotyppisesti käyttäytyvien kettujen osuus aktiivisista ketuista (Norja: 2,9 \%, Suomi: $2,9 \%$ ) ei eronnut maiden välillä ( $\chi^{2}$ ja MannWhitney: $\mathrm{p}>0,05)$. Hopeaketuilla esiintyi enemmän stereotyyppistä käyttäytymistä kuin siniketuilla (hopeakettu: $2,8 \%$, sinikettu: $0,7 \% ; \chi^{2}: \mathrm{p}<0,05$ ), mutta aktiivisuuteen suhteutetun stereotyyppisen käyttäytymisen osuudessa lajien välillä ei ollut eroa (Sinikettu: 1,3\%, Hopeakettu: 3,8 \%; KW: $\mathrm{p}>0,05)$. Eri eläintyyppien välillä ei ollut eroja stereotyyppisesti käyttäytyvien yksilöiden määrässä (urokset: $0 \%$, pennuttomat naaraat: $2,5 \%$, pentuja hoitavat naaraat: $1,9 \%$, sukupuoli epäselvä: $1,5 \%$; $\left.\chi^{2}: p>0,05\right)$ tai aktiivisuuteen suhteutetun stereotyyppisen käyttäytymisen määrässä (urokset: $0 \%$, pennuttomat naaraat: $4,0 \%$, pentuja hoitavat naaraat: $2,7 \%$, sukupuoli epäselvä: $2,4 \%$; KW: $\mathrm{p}>0,05)$.Tulosten osoittavat, että stereotyyppistä käyttäytymistä esiintyy turkistiloilla vähän. WelFur mittaristoon kehitetty menetelmä on nopea ja soveltuu stereotyyppisen käyttäytymisen määrään mittaamiseen tilatasolla, ja sillä voidaan erottella tiloja stereotyyppisen käyttäytymisen määrän mukaan. Mittarin luotettavuutta on kuitenkin vielä syytä tutkia.

Asiasanat: sinikettu, hopeakettu, stereotyyppinen käyttäytyminen, hyvinvointi, hyvinvoinnin arvioiminen

\section{Johdanto}


Vuonna 2009 alkaneen WelFur-hankkeen tarkoituksena on kehittää arviointimenetelmä turkiseläinten hyvinvoinnin arvioimiseen tilatasolla. WelFur-hankkeessa kehitettävä arviointimenetelmä noudattaWelfare Quality ${ }^{\circledR}$-arviointimenetelmän periaatteita ja kriteerejä. Tavoitteena on, että ketuille (sinikettu ja hopeakettu) ja minkille kehitettävät mittarit ovat tieteellisiin tutkimustuloksiin pohjaavia ja luotettavia hyvinvoinnin mittareita.

Stereotyyppinen käyttäytyminen on muuttumattomana toistuvaa ja näennäisesti merkityksetöntä käyttäytymistä (Mason 2006). Stereotyyppistä käyttäytymistä havaitaan vankeudessa elävillä eläimillä. Stereotyyppisen käyttäytymisen esiintymistä voidaan pitää merkkinä eläimen heikentyneestä hyvinvoinnista, erityisesti turhautumisesta ja stressistä, jotka usein ovat seurausta puutteellisista kasvatusolosuhteista (Mason 2006). Stereotyyppistä käyttäytymistä esiintyy myös tarhatuilla ketuilla , mutta kuten Anttilan ym. (2010) katsausartikkelissa todetaan, systemaattista tutkimustietoa kettujen stereotyyppisen käyttäytymisen esiintyvyydestä on varsin vähän. Mutta, stereotyyppistä käyttäytymistä pidetään kuitenkin niin selvänä heikentyneen hyvinvoinnin indikaattorina, ja se on mukana myös Welfare Quality $^{\circledR}$ arviointimittaristoissa, päätettiin stereotyyppisen käyttäytymisen tilatason esiintyvyys ottaa myös osaksi kehitettävää WelFur-arviointimittaristoa.

Kaikkien WelFur-arviointimittaristoon sisältyvien mittareiden tulee olla tieteellisesti perusteltuja, luotettavia ja käyttökelpoisia. Mittarin käyttökelpoisuuteen vaikuttaa ennen kaikkea mittarin helppous tilalla. Mittaamiseen ei voida kenttäolosuhteissa käyttää monimutkaisia mittauslaitteistoja, mittarin tulee soveltua kaikkiin olosuhteisiin ja mittaamisen täytyy tapahtua nopeasti, jotta riittävä otoskoko saavutetaan yhden työpäivän aikana. Kettujen stereotyyppistä käyttäytymistä on aiemmin tarkkailtu videotallenteista (katso esimerkiksi Korhonen ym. 2001; Ahola ym. 2002; Wikman 2003; Koistinen ym. 2009) tai suoralla seurannalla (esimerkiksi Wikman 2003), mutta validoitua testiä stereotyyppisen käyttäytymisen tarkkailuun ei ole tehty. WelFur-hankkeen aikana kehitettiin yksinkertainen stereotyyppisen käyttäytymisen mittausprotokolla.

Tämän työn tavoitteena oli arvioida stereotyyppistä käyttäytymistä tilatasolla mittaavan mittarin käyttökelpoisuutta ja soveltuvuutta erilaisiin turkistilaolosuhteisiin. Lisäksi tavoitteena oli tutkia stereotyyppisen käyttäytymisen yleisyyttä eri kettulajeilla (sinikettu ja hopeakettu) ja eläintyypeillä (urokset, pennuttomat naaraat, pentuja hoitavat naaraat) lisääntymiskauden aikana.

\section{Aineisto ja menetelmät}

Mittaria testattiin turkistiloilla Norjassa $(\mathrm{N}=6)$ ja Suomessa $(\mathrm{N}=4)$ kesä-heinäkuussa 2011. Tilakäynneille osallistui neljä arvioijaa, jotka arvioivat Norjassa yhteensä 862 kettua joista $5 \%$ oli sinikettuja ja $95 \%$ hopeakettuja, ja Suomessa 831 kettua joista $77 \%$ oli sinikettuja ja $23 \%$ hopeakettuja. Kaksi arvioijista (I, II) oli mukana kaikilla turkistiloilla sekä Norjassa että Suomessa. Kolmas arvioijista (III) oli mukana arvioimassa turkistiloja vain Norjassa ja neljäs (IV) arvioija vastaavasti vain Suomessa.

Kultakin tilalta valittiin tilan eläinkantaa hyvin edustava otos. Keskimäärin kettuja tarkkailtiin 169 yksilöä per tarha. Otoksen osuus koko tarhan eläinkannasta oli pienimmillään $6 \%$ ja suurimmillaan $79 \%$ (Kaikkien tarhojen keskiarvo: $41 \pm 27 \%, \mathrm{Ka} \pm \mathrm{SD}$ ).

Stereotyyppisen käyttäytymisen tilatason esiintyvyyttä mitattiin varjotalossa tai hallissa tarkkailemalla 8-12 ketun ryhmiä aamulla ennen ruokintaa (Kuva 1). Tarkkailun aikana kirjattiin ylös yksilöittäin aktiivisuus (aktiivinen vs. lepää) ja stereotyyppinen käyttäytyminen. Menetelmässä tarkkailija käveli varjotaloon ja seisahtui käytävälle kohteena olevien kettujen keskelle. Ryhmän annettiin tottua tarkkailijan läsnäoloon kolmen minuutin ajan, jonka aikana tarkkailija hitaasti liikuskeli paikallaan. Tämän jälkeen tarkkailija asettautui käytävän suunteisesti ja tarkkaili käytävän molemmilla puolin olevien kettujen (4-6) käyttäytymistä minuutin ajan. Tarkkailujakson jälkeen kirjattiin oliko kettu suurimman osan tarkkailuajasta aktiivinen vai lepäsiko se ja käyttäytyikö se stereotyyppisesti vai ei. Tämän jälkeen tarkkailija kääntyi ympäri ja toisti tarkkailun toiselle 4-6 ketun ryhmälle. Stereotyyppisen käyttäytymisen esiintyminen suhteutettiin aktiivisten yksilöiden määrään. 


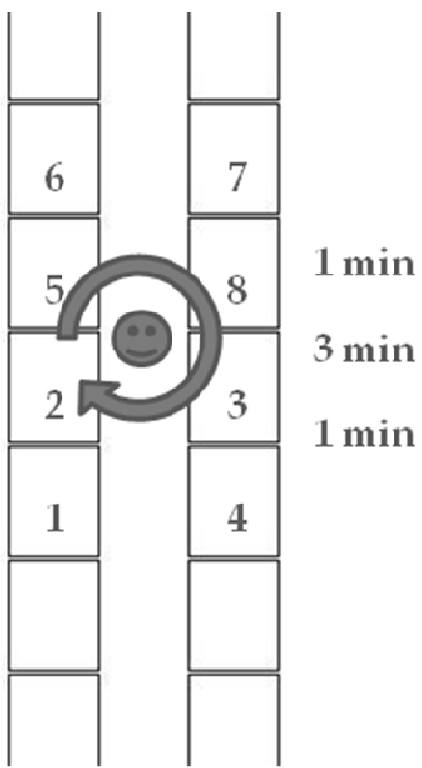

Kuva 1. Stereotyyppiseen käyttäytymiseen käytetty tarkkailumenetelmä. Varjotaloon saapuessaan tarkkailija antoi kettujen tottua läsnäoloonsa kolmen minuutin ajan. Totuttautumisajan jälkeen hän tarkkaili ensin 4-6 kettua samanaikaisesti yhden minuutin ajan (kuvassa ketut 1-4), jonka jälkeen kääntyi ympäri ja tarkkaili jälleen 4-6 kettua minuutin ajan (kuvassa ketut 5-8).

Tulosten analysointi tehtiin SPSS tilastonkäsittelyohjelmalla. Stereotyyppisen käyttäytymisen esiintyvyys testattiin $\chi^{2}$-testillä. Stereotyyppisesti käyttäytyvien kettujen osuus aktiivisista ketuista testattiin Kruskal-Wallisin testillä ja Mann-Whitneyn testillä.

\section{Tulokset ja tulosten tarkastelu}

\section{Maiden ja tarhojen väliset erot stereotyyppisen käyttäytymisen esïntyvyydessä}

Stereotyyppisen käyttäytymisen tarkkailu onnistui hyvin molemmissa maissa kaikilla turkistiloilla. Esimerkiksi Norjassa pakolliset, häkkiin laitettavat tuulensuojat estävät näkyvyyttä häkin ulkopuolelta, mutta koska tarkkailu tapahtui varjotalon sisäpuolella, tuulensuojista ei juurikaan ollut haittaa. Stereotyyppisen käyttäytymisen mittaamiseen kehitetty menetelmä siis näyttäisi olevan käyttökelpoinen erilaisissa olosuhteisiin.

Kaikkiaan stereotyyppistä käyttäytymistä havaittiin ketuilla vähän. Yhdellä tilalla Suomessa ja kahdella tilalla Norjassa ei havaittu stereotyyppistä käyttäytymistä tarkkailun aikana. Stereotyyppisesti käyttäytyvien eläinten osuus kaikista tarkkailluista eläimistä (Norja: 2,1 \%, Suomi: 1,8 \%) tai stereotyppisesti käyttäytyvien kettujen osuus aktiivisista ketuista (Norja: 2,9 \%, Suomi: 2,9 \%) ei eronnut maiden välillä $\left(\chi^{2}\right.$ ja Mann-Whitney: $\left.p>0,05\right)$. 


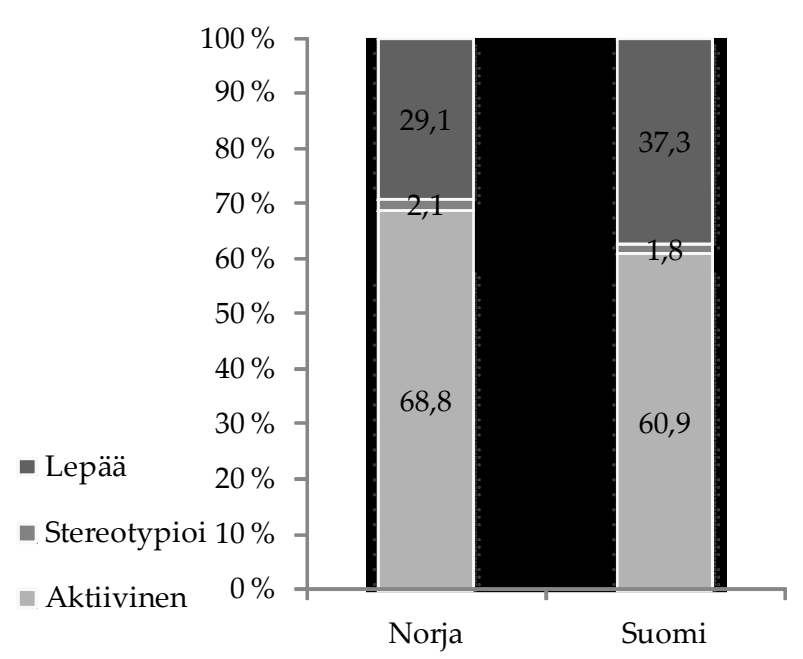

Kuva 2. Stereotyyppisesti käyttäytyvien, aktiivisten ja lepäävien kettujen osuudet kaikista tarkkailluista ketuista Norjassa ja Suomessa.

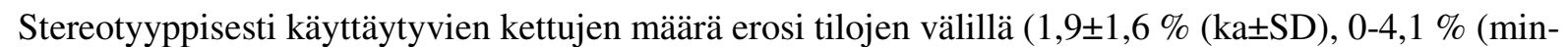
$\left.\max ) ; \chi^{2}: p<0,05\right)$, mutta aktiivisuuteen suhteutetun stereotyyppisen käyttäytymisen määrässä ei tilojen välillä ollut eroja $(2,8 \pm 2,2 \%, 0-4,9 \%$; Kruskal-Wallis: $p>0,05)$.

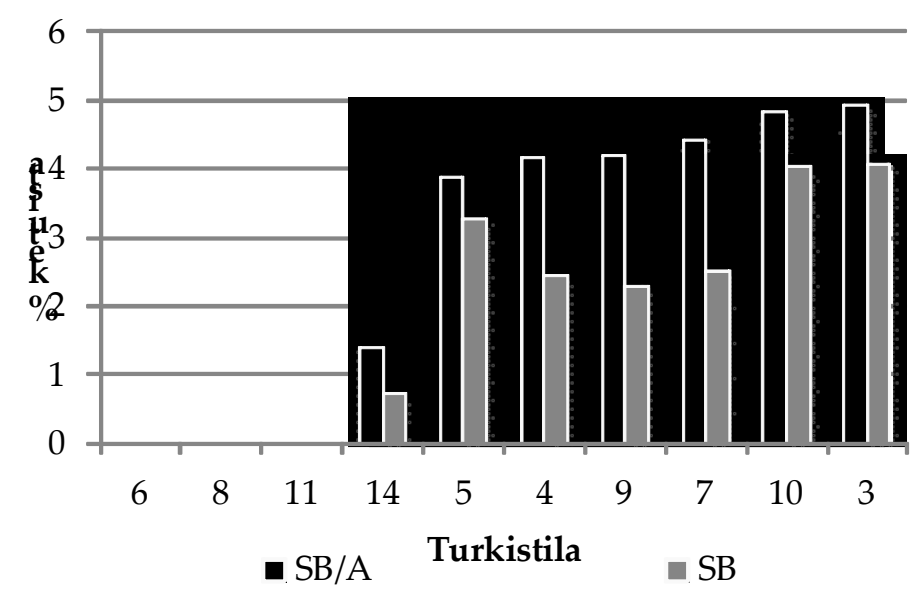

Kuva 3. Stereotyyppisesti käyttäytyvien kettujen osuus (SB) ja stereotyyppisesti käyttäytyvien kettujen osuus aktiivisista ketuista (SB/A) tiloittain. Tilat 3-8 Norja ja 9-14 Suomi.

\section{Stereotyyppinen käyttäytyminen hopeaketulla, siniketulla ja eri eläintyypeillä}

Kaikista tarkkailluista hopeaketuista $73 \%$ ja siniketuista $57 \%$ oli aktiivisia tarkkailun aikana. Hopeaketuilla esiintyi enemmän stereotyyppistä käyttäytymistä kuin siniketuilla (Hopeakettu: 2,8 \%, Sinikettu: $\left.0,7 \% ; \chi^{2}: p<0,05\right)$, mutta aktiivisuuteen suhteutetun stereotyyppisen käyttäytymisen osuudessa lajien välillä ei ollut eroa (Sinikettu: 1,3\%, Hopeakettu: 3,8 \%; KW: p>0,05). 


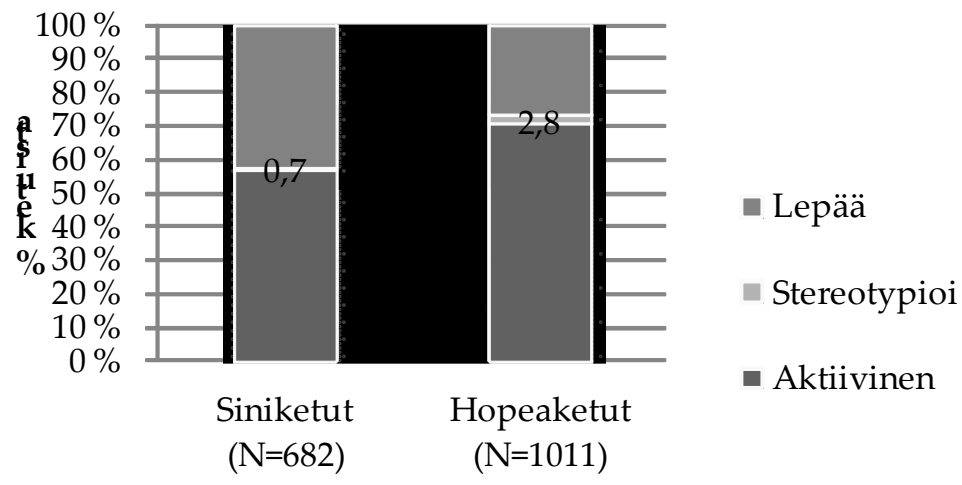

Maat yhteensä Maat yhteensä

Kuva 4. Stereotyyppisesti käyttäytyvien, aktiivisten ja lepäävien sinikettujen ja hopeakettujen osuudet.

Myöskään eri eläintyyppien välillä ei ollut eroja stereotyyppisesti käyttäytyvien yksilöiden määrässä (urokset: $0 \%$, pennuttomat naaraat: $2,5 \%$, pentuja hoitavat naaraat: $1,9 \%$, sukupuoleltaan epäselvät: $\left.1,5 \% ; \chi^{2}: \mathrm{p}>0,05\right)$ tai aktiivisuuteen suhteutetun stereotyyppisen käyttäytymisen määrässä (urokset: $0 \%$, pennuttomat naaraat: 4,0 \%, pentuja hoitavat naaraat: 2,7 \%, sukupuoli epäselvä: 2,4 \%; $\mathrm{KW}: \mathrm{p}>0,05)$.

\section{Pohdinta}

Tässä tutkimuksessa $0,7 \%$ siniketuista ja 2,8 \% hopeaketuista käyttäytyi stereotyyppisesti. Hopeaketut olivat sinikettuja aktiivisempia ja stereotyyppisesti käyttäytyvien yksilöiden osuus oli hopeaketuilla suurempi kuin siniketuilla. Vaikka lajien välillä ei ollut tilastollisesti merkitsevää eroa stereotyyppisesti käyttäytyvien yksilöiden osuudessa aktiivisista yksilöistä, tulokset viittaavat siihen, että stereotyyppisen käyttäytymisen osuus aktiivisesta käyttäytymisetä on hopeaketuilla hieman suurempi kuin siniketulla. Vastaavia tuloksia lajien välisestä erosta stereotyyppisen käyttäytymisen esiintyvyydestä on saatu myös aiemmissa tutkimuksissa (Wikman 2003), mutta saamamme tulokset stereotyyppisen käyttäytymisen esiintyvyydestä olivat hieman aiempia tuloksia alhaisempia. Wikman (2003) vertaili stereotyyppisen kättäytymisen esiintyvyyttä sini- ja hopeaketuilla viidellä eri turkistilalla: noin 5,3 \% siniketuista ja 9,9 \% hopeaketuista esiintyi liikkumiseen liittyvää stereotyyppistä käyttäytymistä. Kun huomioon otettiin kaikki stereotyyppinen käyttäytyminen muodot, stereotyyppisesti käyttäytyvien yksilöiden osuus oli 8,5\% siniketuista ja 11 \% hopeaketuista. Syitä Wikmanin (2003) korkeampaan stereotyyppisen käyttäytymisen esiintyvyyteen voivat olla erilainen käyttäytymisen tarkkailumenetelmä, sekä erilaiset stereotyyppisen käyttäytymisen määritelmät, mutta myös vuosia jatkunut jalostusvalinta.

Muihin turkiseläimiin verrattuna ketuilla esiintyy stereotyyppistä käyttäytymistä verrattain vähän. Esimerkiksi Mason (1993) havaitsi, että jopa 90 - $100 \%$ täysikasvuisista naarasminkeistä käyttäytyi stereotyyppisesti ruokinta-ajan lähestyessä lisääntymiskauden aikana. Ruokinnan jälkeen 4960\% käyttäytyi stereotyyppisesti. Myös Hansen ja Jeppesenin tutkimuksessa (2006) kokeeseen valituista 290:sta vuoden ikäisestä minkkinaaraasta 75\% käyttäytyi stereotyyppisesti. WelFur-hankkeen aikana minkin arviointimittariston kehitystä varten kerätyn aineiston mukaan tilojen välinen vaihtely stereotyyppisesti käyttäytyvien minkkien osuudessa aktiivisista eläimistä oli 40 - $62 \%$ parituskaude aikana (Møller \& Hansen 2011). Supikoirien stereotyyppisen käyttäytymisen esiintyvyydestä tehtyjä laajamittaisempia tutkimuksia on varsin vähän, mutta esimerkiksi Aholan ym. (2007) tekemässä tutkimuksessa $83 \%$ pareittain kasvatetuista supikoirista käyttäytyi stereotyyppisesti loppukesällä tuotan- 
tokauden aikana, ja myöhemmin syksyllä 66 \% pareittain kasvatetuista supikoirista käyttäytyi stereotyyppisesti.

Eri eläintyyppien välillä ei havaittu eroa stereotyyppisen käyttäytymisen määrässä tai aktiivisuuteen suhteutetun stereotyyppisen käyttäytymisen määrässä. Urosten ei havaittu käyttäytyvän stereotyyppisesti tutkimuksen aikana. Tämä lienee seurausta pienestä otoskoosta. Lisääntymiskaudella uroksia on tiloilla vain muutamia yksilöitä. Kokonaisuudessaan urosten osuus kaikista ketuista oli 3,5\% $(n=60)$.

Käyttämällämme mittarilla havaittiin eroja stereotyyppisen käyttäytymisen esiintyvyydessä tarhojen välillä, mutta ei aktiivisten eläinten määrään suhteutetussa stereotyyppisen kättäytymisen määrässä. Kun WelFur arviointeja ryhdytään toteuttamaan turkistiloilla, käytännön kannalta tärkeintä ei ole se, että tilojen välinen hajonta on tilastollisesti merkitsevä. Tärkeintä on, että turkistilojen välillä on riittävästi hajontaa, jotta tilat voidaan erotella aktiivisuuteen suhteutetun stereotyyppisen käyttäytymisen esiintyvyyden mukaan. Tulostemme perusteella tiloja voitaisiin tulevaisuudessa erotella stereotyyppisen käyttäytymisen esiintyvyyden mukaan.

Yleisestiottaen mittausmenetelmä oli helppokäyttöinen ja nopea. Mittaaminen onnistui kaikenlaisissa turkistilaolosuhteissa. Menetelmän avulla saadut tulokset ovat samansuuntaisia aiempien tulosten kanssa, joten sen voidaan olettaa olevan verrattain luotettava. Menetelmää ei kuitenkaan ole vielä validoitu, joten lisätutkimukset menetelmän luotettavuudesta ovat tarpeen.

\section{Johtopäätökset}

Kesällä 2011 kerätyt tulokset osoittavat, että stereotyyppistä käyttäytymistä esiintyy turkistiloilla vähän lisääntymiskaudella. Stereotyyppisen käyttäytymisen esiintyvyydessä ei ole eroa Suomen ja Norjan välillä. Turkistilojen välillä on eroja stereotyyppisen käyttäytymisen esiintyvyydessä. Hopeaketuilla esiintyy ehkä hieman enemmän stereotyyppistä käyttäytymistä kuin siniketulla, mutta tässä aineistossa eri eläintyyppien välillä ei havaittu eroja. WelFur-arviointimittaristoon kehitetty mittari soveltui stereotyyppisen käyttäytymisen mittaamiseen erilaisissa olosuhteissa ja tarkkailu sujui nopesti. Menetelmä soveltuu stereotyyppisen käyttäytymisen määrää mittaamiseen tilatasolla ja sillä voidaan erottella hyvinvointimittaristossa tiloja stereotyyppisen käyttäytymisen määrän mukaan, mutta mittarin luotettavuutta on vielä syytä tutkia.

\section{Kirjallisuus}

Ahola, L., Mononen, J., Pyykönen, T. \& Mohaibes, M. 2002. Effects of group size and space allocation on physiological, behavioural and production-related welfare parameters in farmed silver foxes. Agricultural and Food Science in Finland. 11:185-197

Ahola, L., Hänninen, S. \& Mononen, J. 2007. A Note on Stereotyped Behaviour in Pair and Group-housed Farmed Juvenile Raccoon Dogs. App. Anim. Behav. Sci. 107:174-180

Anttila, R., Koistinen, T., Mononen, J. \& Ahola, L. 2010. A review of stereotypic behaviour in farmed foxes. Proceedings of the NJF Seminar no 440. 29 September - 1 October 2010, Oslo, Norway

Hansen, S. \& Jeppesen, L. 2006. Temperament, Stereotypies and Anticipatory Behaviour as Measures of Welfare in Mink. App. Anim. Behav. Sci. 99:172-182

Koistinen, T., Turunen, A. \& Korhonen, H.T. 2009. Blue foxes' (Alopex Lagopus) preferences between earth floor and wire mesh floor. Appl. Anim. Behav. Sci. 120:192-200

Korhonen, H., Niemelä, P. \& Jauhiainen, L. 2001. Effect of Space Allowance and Floor Material on the Behaviour of Farmed Blue Foxes. Can. J. Anim. Sci. 81:189-197

Mason, G. 1993. Age and Context Affect the Stereotypies of caged Mink. Behaviour 127: 191-229

Mason, G. 2006. Stereotypic Behaviour in Captive Animals. Teoksessa: Animal Behaviour: Fundamentals and Applications to Welfare. $2^{\text {nd }}$ ed. G. Mason \& J. Rushen (toim.), CABI, Wallingford, Iso-Britania. s. 325-356. 367 s.

Møller, S.H. \& Hansen, S.W. 2011.Testing the WelFur assessment protocol for mink on-farm in three seasons of production. Proceedings of the NJF-Seminar no. 450. Fur Animal Research, Autumn Meeting, 1-3 November 2011, Knivsta, Sweden 
Wikman, I. 2003. Stereotypier hos blårävar (Alopex lagopus) och silverrävar (Vulpes vulpes) på pälsdjursfarmer. Pro gradu. Ekologian ja systematiikan laitos, Helsingin yliopisto, Helsinki, Suomi. 50 s. 